\title{
Effect of Advertising Expenses and Sales Incentives on Financial Performance: Dissecting the Cases of Two Market Leaders
}

\author{
Madhobi Hossain (Corresponding Author) \\ School of Business Studies, Southeast University \\ House-64, Road-18, Block-B, Banani-1213, Dhaka, Bangladesh \\ Tel: 880(2)-5503-4125Ｅ-mail: madhobi.h@gmail.com \\ Tiasha Islam \\ School of Business Studies, Southeast University \\ House-64, Road-18, Block-B, Banani-1213, Dhaka, Bangladesh \\ Tel: 880(2)-5503-4125 E-mail: tiashaislam@gmail.com
}

Received: December 9, 2018 Accepted: December 20, 2018 Published: December 28, 2018

doi:10.5296/ber.v9i1.14019 URL: https://doi.org/10.5296/ber.v9i1.14019

\begin{abstract}
There has been much interest among academicians and practitioners to understand the role of marketing expenses in contributing to the financial performance of organizations. Especially, in times of recession, budget reduction, or market contraction, marketing budgets get the major cut. However, organizations continue to spend millions in the development and execution of marketing programs. This paper examines the effect of advertising and sales incentives on the revenue and profit of Grameenphone and bKash, who are the market leaders in their respective industries of Bangladesh. With the help of secondary data, it has been found that there is a negative relationship between advertising and financial performance (i.e. revenue and profit), but sales incentives on the other hand have a positive relationship with revenue and profit.
\end{abstract}

Keywords: Marketing expenses, Financial performance, Advertising, Sales incentives, Revenue and profit 


\section{Introduction}

The contribution of marketing in the financial performance of organizations has been a subject of considerable debate in the past years, but the insistence to establish the marketing-finance interface has gained a greater attention, as marketers strive to defend the value of their activities amidst budget cuts (Morgan, 2011). Traditionally, marketing activities have been designed from the viewpoint of customers (Joshi \& Hanssens, 2010), because eventually, these regulate the mechanism of attracting, acquiring and retaining customers (Chowdhury, 2017). However, when organizations are faced with the dilemma of reducing cost, marketing expenditures are the primary facet of the budget to be criticized (Sharma \& Husain, 2015).

On the other hand, it is argued that effective marketing or promotional activities, such as advertising; personal selling; sales commission and incentives; and interactive marketing could result in the achievement of long-term objectives and higher financial returns (Rehman et al., 2015). Numerous researchers have tried to emphasize on the linkage between marketing and the essential role it plays in the enhancement of organizational performance (Balasubramanian \& Bhardwaj, 2004), in terms of sustained growth and profitability (Makadok, 2001; Malhotra \& Sharma, 2002). Hooley et al., 2005, state that marketing has an indirect impact on the financial performance of an organization with the mediating factors being customer satisfaction, loyalty and superior market performance, whereas Srinivasan \& Hanssens (2009) pointed out that marketing expenditure has a direct effect on investors. Similarly, advocates of marketing, relate its activities to the opportunity of gaining competitive advantages (Adcock, 2000; Pride \& Ferrell, 1997; Jolibert et al., 2012). Recent advances in this paradigm have triggered the investigation of marketing activities' impact on firm's accounting and financial market performance (Morgan, 2011).

Despite affirming to the underlying relation between marketing activities, and organization's sales and profitability in several studies (Joshi \& Hanssens, 2010), the issues concerning marketing budgets, especially advertising, are still found vulnerable (Lodish \& Mela, 2007). Conversely, in the context of Bangladesh, there is no adequate evidence or literary work to put light on this theory. Since businesses operate with the primary purpose of maximizing the return of shareholders' investments, according to the shareholder value principle (Joshi \& Hanssens, 2010; Osinga et al., 2011), investigation of this subject area is deemed important.

Most of the organizations in Bangladesh, do not provide a thorough breakdown of their marketing expenses in their annual reports; however, the marketing related costs that were commonly presented in the majority of the reports were advertising and sales commission/incentives. Hence, the primary motivation of conducting this research is to investigate the effect of advertising and sales incentives on the financial performance of two companies, namely, Grameenphone (i.e. a telecommunication company) and bKash (i.e. a mobile financial service provider), who are also the market leaders in their respective industries (Husain, 2017; Wang Hai, 2018). According to several academicians, sales revenue and profit are considered the most important metrics for the measurement of financial performance (Narver \& Slater, 1990; Clark, 2000); thus, these two have been used as the 
main financial indicators. This paper is aimed to not merely contribute academically, but also provide an opportunity for other organizations in the particular industries to comprehend the significance of marketing expenses and the extent to which these can influence the revenue and profit of an organization, because eventually this is what the shareholders seek to achieve.

\section{Literature Review}

In a dynamic market environment that is challenged with constant change in demands and severe competition, organizations have found the need to employ various marketing communication tools in order to attract and retain customers. Numerous studies and academic research for this purpose have been carried out to evaluate the effectiveness of various marketing actions, such as advertising, sales incentives, and sponsorship, on the augmentation of shareholder value (Osinga et al., 2011). In a research by Lodish et al., 1995, the findings revealed that TV advertisements impacted sales in the short run, but not in the long run. Resultantly, this raises skepticism regarding the big budgets allocated and spent on advertisements. Another research, carried out over a span of four years by Nijs, et al., 2001, disclosed that although price promotions had a short-term effect, advertisements on the other hand had a long-term effect on sales. Hence, this has been a subject of great interest for many researchers who have over time explored the relationship between marketing communication activities and profitability.

Okeyere et al., 2011, established that an increase in advertising and sales promotion causes the sales volume to increase as well, but the opposite was proved for the relationship between sponsorship and sales. Gautam, 2013, in a similar research on the backdrop of Indian Telecommunication Industry found out that marketing promotion plays an essential role in determining the profitability of the companies. In contrast to the results advocating the positive relationship, a research executed in Nigeria proved that despite the positive correlation between promotion budgets and overall business performance, the same principle does not apply to the small and medium enterprises (Gbolagade et al., 2013). In spite of the variations in the findings, it is intriguing to note that amongst all the related researches, advertising has been the most commonly observed marketing communication tool.

\subsection{Advertising and Financial Performance}

According to Armstrong and Kotler, 2000 (cited by Richard and Curran, 2002, p.65), advertising is "any paid form of non-personal presentation and promotion of ideas, goods, or services by an identified sponsor." Lamb, Hair and McDaniel, 2000 (cited by Richard and Curran, 2002, p.65), further added that it is an "impersonal, one-way mass communication about a product or organization that is paid for by a marketer."

Many academicians have argued over this notion that advertising has the capability of capturing potential customer's attention, driving a positive buying attitude, and eventually encouraging consumer response (Riaz et al., 2015). Contrariwise, there are two schools of thoughts: one argues that advertising increases profit by creating false product differentiation and amplifying the entry barriers for other companies; the other suggests advertising has 
informative character that can shape the market to be more competitive and distributing the profits to more companies sharing the market (Greuner et al., 2000). Simester et al., 2009, added that advertising undoubtedly affects sales, but the long-run result is not always positive. Nevertheless, the benefits of advertising for an organization cannot be shunned, as it continues to reflect in the expenditure of many bigger names in the market. For instance, in the year 2016, China's largest online retailer, Alibaba accounted for a 50-percent rise in their advertising and promotional spending. Furthermore, Amazon has exceeded other marketers like Coca-Cola and McDonald's in their advertising expenditure, and has been positioned as one of the highest ranked global advertisers (Johnson, 2017).

Lee et al., 1996, found out a two-way causal relationship between advertising and sales. Advertising is believed to influence the consumer's mindset and taste, which eventually contributes to the purchase behaviour of consumers. Alternatively, the other direction of the causality claims that sales and profits possess the key to determine advertising budget. This causality was then criticized in the findings of Leach, 1996 (cited by Chowdhury, 2017), where the former causal relationship was proved, but the latter, i.e. sales causing advertising expenditure, was rejected. Some other research, such as the one done by Elliot, 2002 (cited by Linson \& Thomas, 2016), suggests there is a substantial effect of advertising on sales turnover in the food industry; and a measurable effect in the soap manufacturing companies as highlighted by Linson \& Thomas, 2016. Similarly, Kambar (2002) and Sundarsan (2007) provided evidence of a positive relationship in context of different company sizes. Hence, it would be interesting to find out whether advertising in the context of Bangladesh, has a significant impact on financial performance, and if so, whether it is a positive or a negative relationship. Based on the above-discussed literature, the hypothesis established is as follows:

$\mathrm{H}_{1}$ : There is a significant relationship between advertising expenses and financial performance.

\subsection{Sales Incentives and Financial Performance}

Sales incentives are considered as an important marketing tool through which superior performance is derived from the sales force, so that sales volume is increased in return. Usually sales incentives are categorized into two groups: monetary incentives (i.e. commission, bonus system, share of profits, and cash rewards), and the other being non-monetary incentives (i.e. merchandise awards, travel awards, and sales contests) (Arbatt, 1989, p.209). As quoted by Couretas, 1985 (cited by Arbatt 1989, p.210), the primary objective of incorporating sales incentives into the marketing program of an organization is "to increase sales per salesperson". However, during times of market contraction, managers are often faced with the challenge to reduce costs and simultaneously improve sales. In such situation, decisions regarding instilling sales incentive program in the budget becomes complicated, because it incurs cost, but at the same time it is needed to raise sales volume (Jiménez et al., 2013).

A major criticism of sales incentives is the notion that it may compel the sales force to have a more unproductive short-term focus, consequently resulting in less concentration on long-term goals and development of future selling skills (Zoltners et al., 2012). Deming 
(1986) proposed sales incentives to not be accepted as a motivator for salespeople, which was further advocated by Kohn (1993) who argued that sales incentives fail to produce an enduring commitment to any goal. However, in reality, most businesses discard these arguments (Zoltners et al., 2012). Sales incentives are not only used to generate sales volume, but nowadays it is more about creating profitable sales volume and thus, a decision regarding this should be carefully analyzed (Spiro et al., 2003). For instance, in 2012, the CEO of J.C. Penny, an American department store, eliminated the sales commission from their sales program, with the aim to enhance the business performance (Bhasin, 2012). As a result, the company faced huge loss and eventually had to bring back the commission-based pay system to stimulate sales growth (O'Reilley, 2014; Ryan, 2014). Thus, it is argued that in companies where sales generation highly depends on selling efforts, incentives play a major role in motivating sales employees to provide additional efforts that can be transformed into higher returns (John \& Weitz, 1989). In case of sales incentives, the academic findings have often failed to match the real scenario, mainly because the subject overlaps in many different domains, such as marketing, organizational behaviour and psychology; and another major reason is that companies hardly allow experiments with their sales-force (Zoltners et al., 2008). Nevertheless, researchers in the past have measured the outcomes of sales incentives in terms of high market share, profitability and sales (Behrman and Perreault, 1982; Piercy et al., 1998). In accordance to the literature discussed, the hypothesis is as follows:

$\mathrm{H}_{2}$ : There is a significant relationship between sales incentives and financial performance.

\section{Research Methodology}

In line with the purpose of this particular research, which is to assess the impact of advertising expenses and sales incentives on financial performance, revenue and profit after tax (PAT) have been used as the main financial indicators; thus, treated as dependent variables. Whereas, among all marketing expenditures, this research focuses on advertising expenses and sales incentives, representing the independent variables. This research is solely based on secondary data and follows the procedure to test causality between the dependent and independent variables.

To test the hypotheses, a quantitative research has been conducted using the secondary data gathered from the audited annual reports of both the organizations (i.e. Grameenphone and bKash), over the span of five years from 2013-2017. Since, these two organizations are market leaders in their respective industries, they are selected to provide an overall view of the contribution that marketing expenses make to their financial returns. The Statistical Package for Social Sciences (SPSS) version 24, have been used to investigate the hypothesized causal relationship through conducting a correlation, followed by regression analysis, in both the cases.

\section{Overview of the Cases}

\section{Case 1- Grameenphone: the leading telecommunication company in Bangladesh}

Grameenphone, which is a part of Telenor, a Norwegian telecommunication company, commenced its operations in 1997 (Grameenphone Financial Report, 2018). Although, they 


\section{Macrothink}

Business and Economic Research

ISSN 2162-4860

2019, Vol. 9, No. 1

are not the first to start the telecommunication business in Bangladesh, they still found their way to success, having 65.8 million mobile phone subscriptions out of the total 147 million as of January 2018 (BTRC, 2018). In the year 2016, their market share was 46.29\% (Islam, 2016), proving that, albeit gripping competition from other companies, they persist to possess the highest share of the market.

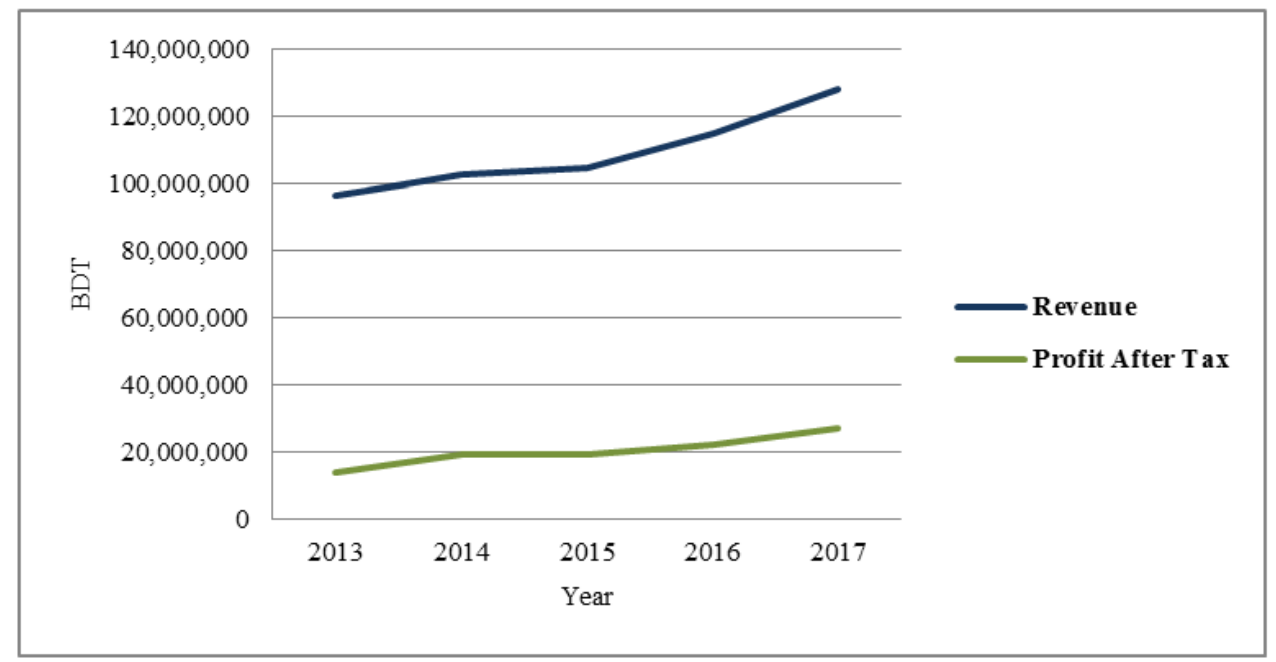

Figure 1. Revenue and PAT figures of Grameenphone (Financial reports, 2013-2017)

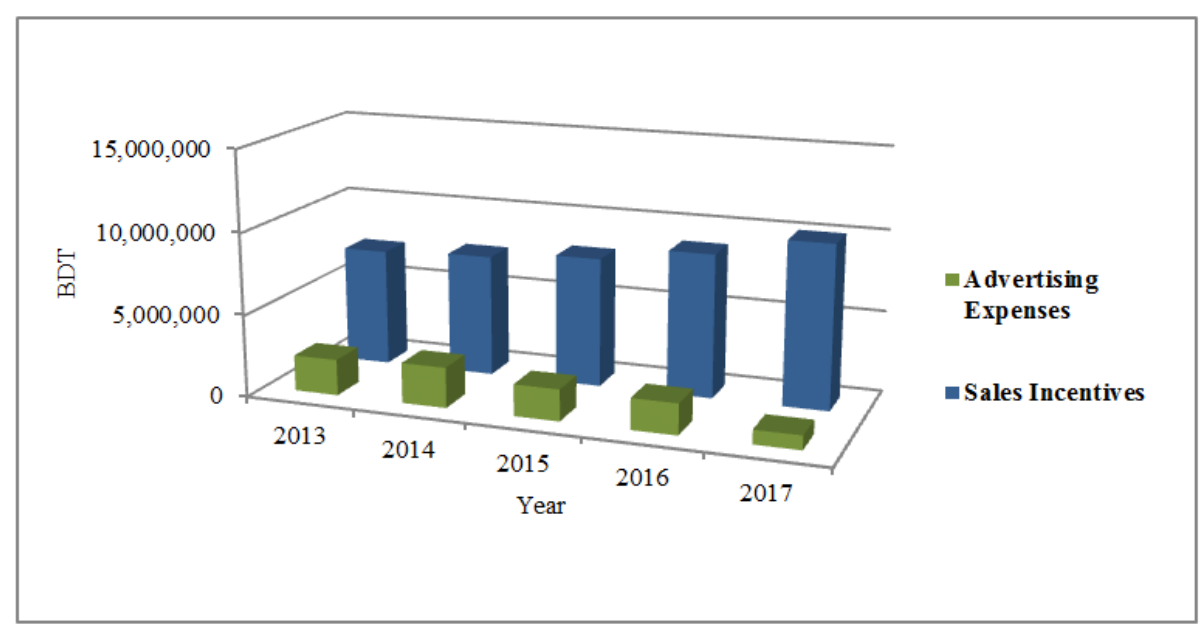

Figure 2. Advertising Expenses and Sales Incentives of Grameenphone (Financial reports, 2013-2017)

The increasing sales revenue and profit figures, over the span of five years (i.e. Year 2013-2017) have been illustrated in Figure-1. The expenditures for advertising and sales incentives are represented in Figure-2. It is intriguing to note that the expenditure for sales incentives increased, whereas the amount of advertising expenditure decreased.

Case 2- bKash: the leading mobile financial service in Bangladesh

bKash, a subsidiary of BRAC Bank, first started its operation in the year 2011, when the Government issued 28 licenses for mobile financial services, under the direction of 


\section{Macrothink}

Business and Economic Research

ISSN 2162-4860

2019, Vol. 9, No. 1

Bangladesh Bank (i.e. the central bank of the country). The emergence of this market was due to the realization that around 70 percent of the people live in rural areas, with only 15 percent having access to banking services (Du Juan, 2018). Since, the subsidiary is a part of BRAC Group, a social enterprise, their primary purpose is to simply enable those who lack bank accounts to manage their money and carry out regular payments easily through mobile phones (Quadir, 2015). Today, their business has expanded to such an extent that the mobile financial service market is seemingly running into a monopolistic situation, with the organization accounting for $89 \%$ of the total market share as of 2016 (The Daily Star, 2017).

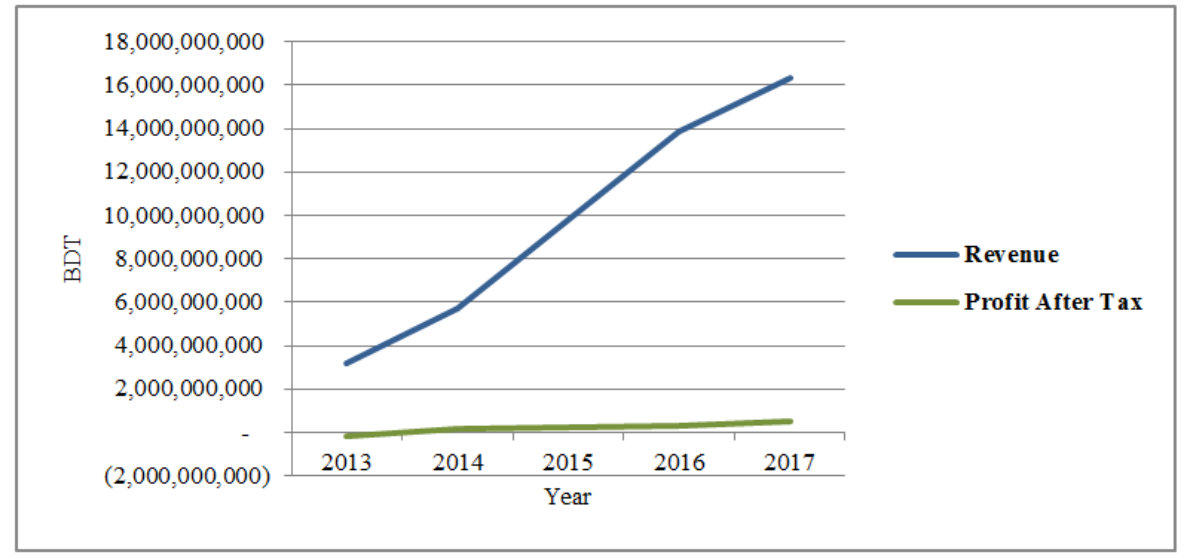

Figure 3. Revenue and PAT figures of bKash (Financial reports, 2013-2017)

Figure-3 represents the increase in sales revenue and profit after tax of bKash from the year 2013 to 2017. However, the disparity between the revenue figures and profit is huge, with a loss in 2013, which could perhaps be due to its parent company being a social enterprise, or also because they have had a huge amount of outside investments in the initial years (Brac Bank Financial report, 2016). Similar to the case of Grameenphone, Figure-4 explains the expenditure for sales incentives is increasing significantly, whereas the advertising expenses are decreasing over time. In contrast, it can be seen that from the year 2013, the advertising expenses increased by a huge amount in 2014 , and then gradually declined.

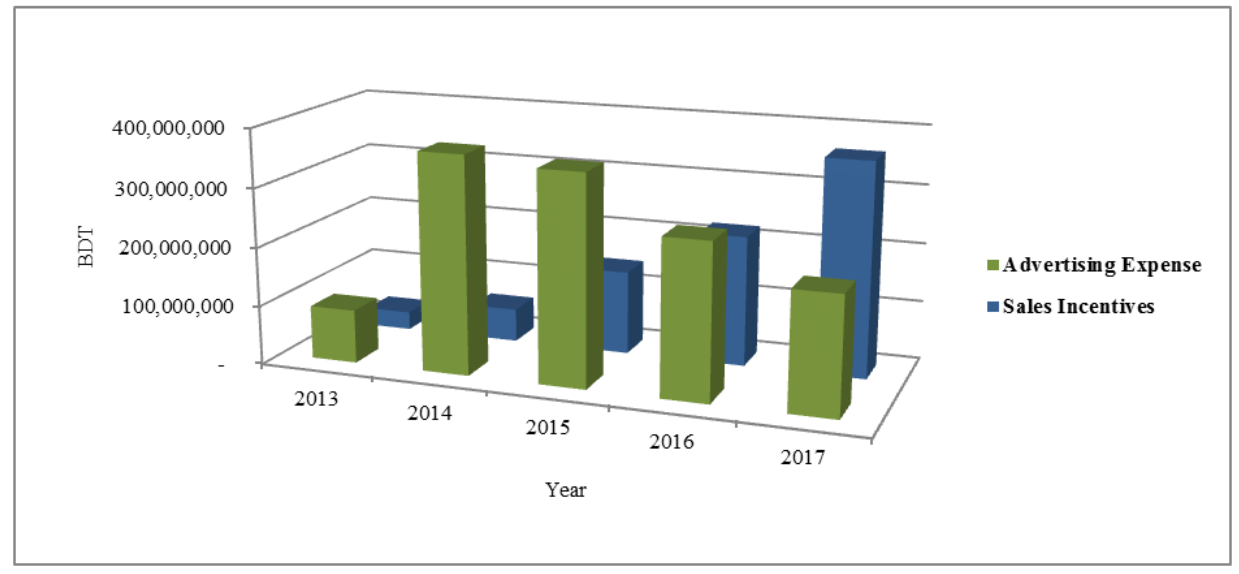

Figure 4. Advertising Expenses and Sales Incentives of bKash (Financial reports, 2013-2017) 


\section{Data Analysis}

\subsection{Analysis for Case 1: Grameenphone}

Table 1. Correlation Coefficients for Case-1 (Grameenphone)

\begin{tabular}{l|c|c|c|c|}
\hline & Revenue & Profit After Tax & Advertisement & Sales Incentives \\
\hline Revenue & 1 & $.968^{* *}$ & $-.905^{*}$ & $.994^{* *}$ \\
\hline Profit After Tax & $.968^{* *}$ & 1 & $-.812^{*}$ & $.943^{*}$ \\
\hline Advertising & $-.905^{*}$ & $-.812^{*}$ & 1 & $-.932^{*}$ \\
\hline Sales Incentives & $.994^{* *}$ & $.943^{*}$ & $-.932^{*}$ & 1 \\
\hline **. Correlation is significant at the 0.01 level (2-tailed). \\
\hline *. Correlation is significant at the 0.05 level (2-tailed). \\
\hline
\end{tabular}

Table 1 denotes the correlation between all the variables derived for the case of Grameenphone. Although, advertising is believed to have a positive impact on revenue and profit, the correlation coefficients state otherwise. The correlation between advertising and revenue is strong, but negative $(\mathrm{r}=-.905, \mathrm{p}<0.05)$, and the same correlation stands with PAT $(\mathrm{r}=-.812, \mathrm{p}<0.05)$. On the contrary, a strong, positive relation can be observed between sales incentives and revenue, and also between sales incentives and PAT $(r=.994, p<.01 ; r=.943$, $\mathrm{p}<.05$ respectively). Moreover, the high correlation between revenue and profit, and advertising and sales incentives are quite apparent.

Table 2. Regression Model 1- Relationship between Advertising \& Financial Performance of Grameenphone

\begin{tabular}{|c|c|c|c|c|c|c|c|}
\hline Variable & $\operatorname{Beta}(\beta)$ & $\mathrm{t}$ & Sig. & Variable & $\operatorname{Beta}(\beta)$ & $\mathrm{t}$ & Sig. \\
\hline (Constant) & & 14.705 & .000 & (Constant) & & 6.308 & .000 \\
\hline Advertising & -.905 & -3.696 & .034 & Advertising & -.812 & -2.412 & .008 \\
\hline $\mathrm{R}$ Square $\left(\mathrm{R}^{2}\right)$ & \multicolumn{3}{|c|}{.820} & $\mathrm{R}$ Square $\left(\mathrm{R}^{2}\right)$ & \multicolumn{3}{|c|}{.660} \\
\hline Adjusted $\mathrm{R}^{2}$ & \multicolumn{3}{|c|}{.760} & Adjusted $\mathrm{R}^{2}$ & \multicolumn{3}{|c|}{.546} \\
\hline \multicolumn{4}{|c|}{ a. Dependent Variable: Revenue } & \multicolumn{4}{|c|}{ a. Dependent Variable: Profit After Tax } \\
\hline
\end{tabular}

Regression analysis has been carried out in order to examine hypothesis 1, the results of which are shown in Table 2. The hypothesis argues that there is a significant relationship between advertising and financial performance (i.e. revenue and profit), which in this case has been accepted because the significance value matches the standard level of acceptance $(\mathrm{p}<0.05)$. However, it is fascinating to find that a negative relationship exists between the variables. This implies an increase in advertisement negatively impacts financial performance. In addition, the strength of association between a dependent variable (revenue, PAT) and an independent variable (advertisement expense) can be explained with the help of $\mathrm{R}^{2}$ (Hössjer, 2008). Here, a strong association is detected, as $82.0 \%$ and $66.0 \%$ of the variation in the dependent variables (i.e. revenue and profit respectively) is explained by the variation in advertising. 


\section{Macrothink}

Table 3. Regression Model 2- Relationship between Sales Incentives \& Financial Performance of Grameenphone

\begin{tabular}{|l|c|c|c|l|c|c|c|}
\hline \multicolumn{1}{|c|}{ Variable } & Beta $(\beta)$ & $\mathrm{t}$ & Sig. & \multicolumn{1}{|c|}{ Variable } & Beta $(\beta)$ & $\mathrm{t}$ & Sig. \\
\hline (Constant) & & 3.615 & .000 & (Constant) & & -1.769 & .005 \\
\hline Sales Incentives & .994 & 16.237 & .001 & Sales Incentives & .943 & 4.888 & .016 \\
\hline R Square $\left(\mathrm{R}^{2}\right)$ & \multicolumn{2}{|c|}{.989} & & R Square $\left(\mathrm{R}^{2}\right)$ & \multicolumn{2}{c|}{.888} \\
\hline Adjusted $\mathrm{R}^{2}$ & \multicolumn{2}{|c|}{.985} & \multicolumn{2}{|c|}{ Adjusted $\mathrm{R}^{2}$} & \multicolumn{2}{c|}{.851} \\
\hline \\
a. Dependent Variable: Revenue
\end{tabular}

Regression model 2 (shown in Table 3) has been carried out to test hypothesis 2 . The hypothesis is accepted because again the significance level reaches the accepted benchmark. Additionally, the positive relationship between sales incentives and revenue, as well as with profit, suggests that an increase in sales incentives causes an increase in financial performance of the firm. The strength of association between the dependent variables and independent variable is quite high, signifying a $98 \%$ of variation in revenue and $88 \%$ in profit are explained by the variation in sales incentives.

From the above analysis, it can be confirmed that advertisement expense and financial performance have a negative relationship, but on the other hand, sales incentives and financial performance have a positive relationship.

\subsection{Analysis for Case 2: bKash}

Table 4. Correlation Coefficients for Case-2 (bKash)

\begin{tabular}{|l|c|c|c|c|}
\hline & Revenue & Profit After Tax & Advertisements & Sales Incentives \\
\hline Revenue & 1 & $.914^{*}$ & -.118 & $.968^{* *}$ \\
\hline Profit After Tax & $.914^{*}$ & 1 & -.455 & $.858^{* *}$ \\
\hline Advertising & -.118 & -.455 & 1 & -.051 \\
\hline Sales Incentives & $.968^{* *}$ & $.858^{* *}$ & -.051 & 1 \\
\hline$*$. Correlation is significant at the 0.05 level (2-tailed). \\
\hline **. Correlation is significant at the 0.01 level (2-tailed). \\
\hline
\end{tabular}

Table 4 represents the results of correlation analysis for bKash, which demonstrates a negative correlation between advertising and revenue ( $\mathrm{r}=-.118)$, and the same negative correlation exists with PAT ( $\mathrm{r}=-.455)$. However, the coefficients are not statistically significant, meaning $\mathrm{p}>0.05$. In contrast, a strong positive relation can be observed between sales incentives and revenue $(\mathrm{r}=.968, \mathrm{p}<.01)$, and also between sales incentives and PAT $(\mathrm{r}=.858, \mathrm{p}<.01)$. Unlike Grameenphone, there is a negative correlation between sales incentives and advertisements; however, the results are not significant enough to be accepted. Furthermore, the positive correlation between revenue and profit is quite strong and evident. 
Table 5. Regression Model 3- Relationship between Advertising \& Financial Performance of bKash

\begin{tabular}{|l|c|c|c|l|c|c|c|}
\hline \multicolumn{1}{|c|}{ Variable } & Beta $(\beta)$ & $\mathrm{t}$ & Sig. & \multicolumn{1}{|c|}{ Variable } & Beta $(\beta)$ & $\mathrm{t}$ & Sig. \\
\hline (Constant) & & 1.116 & .346 & $($ Constant $)$ & & .162 & .882 \\
\hline Advertising & -.118 & -.207 & .850 & Advertising & -.455 & -.885 & .441 \\
\hline R Square $\left(\mathrm{R}^{2}\right)$ & \multicolumn{3}{|c|}{.014} & & R Square $\left(\mathrm{R}^{2}\right)$ & \multicolumn{2}{c|}{.207} \\
\hline Adjusted $\mathrm{R}^{2}$ & \multicolumn{3}{|c|}{.009} & \multicolumn{2}{|c|}{ Adjusted $\mathrm{R}^{2}$} & \multicolumn{3}{c|}{.157} \\
\hline
\end{tabular}

In contrary to the previous case, hypothesis 1 is rejected here because Table 5 indicates that the significance of the causal relationship between advertising and financial performance (i.e. revenue and profit) does not match the standard level of $\mathrm{p}<0.05$. Besides these, only $1.4 \%$ and $20.7 \%$ of the variation in the dependent variables (i.e. revenue and profit respectively) is explained by the variation in advertising, implying a very trivial contribution.

Table 6. Regression Model 4- Relationship between Sales Incentives \& Financial Performance of bKash

\begin{tabular}{|l|c|c|c|l|c|c|c|}
\hline \multicolumn{1}{|c|}{ Variable } & Beta $(\beta)$ & $\mathrm{t}$ & Sig. & \multicolumn{1}{c|}{ Variable } & Beta $(\beta)$ & $\mathrm{t}$ & Sig. \\
\hline (Constant) & & 2.837 & .016 & (Constant) & & -.513 & .044 \\
\hline Sales Incentives & .968 & 6.637 & .007 & Sales Incentives & .858 & 2.898 & .003 \\
\hline R Square $\left(\mathrm{R}^{2}\right)$ & \multicolumn{3}{|c|}{.936} & & R Square $\left(\mathrm{R}^{2}\right)$ & \multicolumn{3}{c|}{.737} \\
\hline Adjusted $\mathrm{R}^{2}$ & \multicolumn{3}{|c|}{.915} & & Adjusted $\mathrm{R}^{2}$ & \multicolumn{3}{c|}{.649} \\
\hline F value & \multicolumn{2}{|c|}{44.051} & F value & \multicolumn{2}{c|}{8.396} \\
\hline a. Dependent Variable: Revenue & \multicolumn{2}{|c}{ a. Dependent Variable: Profit After Tax } \\
\hline
\end{tabular}

Regression model 4 (shown in Table 6) has been conducted to test hypothesis 2. The hypothesis is accepted as the results shown correspond to the standard indicator of significance level (i.e. $\mathrm{p}<0.05$ ). The results further indicate a positive relationship between sales incentives and revenue, as well as sales incentives and profit. This specifies that an increase in sales incentives causes an increase in financial performance of the firm. Furthermore, $\mathrm{R}^{2}$ values are also high which indicates that variation in the dependent variable is highly impacted by the variation in the independent variable.

Hence, according to the findings of this research, advertising expense and financial performance have a negative relationship but not significant enough to be counted; whereas, sales incentives and financial performance have a significant positive relationship.

\section{Conclusion \& Future Scope of Research}

It can be deduced from the research that advertising has a negative association with financial performance in both the organizations: Grameenphone and bKash. However, in case of the latter, the negative relationship is not significant enough to be considered. On the other hand, sales incentives indicate a strong positive relationship with sales revenue and profit after tax of the two organizations. It is intriguing to note that while both the organizations are increasing their sales incentives, the advertising expenses in both the cases show gradual 
reduction. This reflects some of the prior theoretical works, which prove that there is indeed a negative relationship between advertising and sales revenue; and even if there is a positive impact, it is short-lived (Bagwell, 2005; Simester et al., 2009). In addition, there is literary evidence that infers sales incentives are an effective medium to generate sales volume (Spiro et al., 2003; Ryals and Rogers, 2005).

This may imply a number of possibilities: change in demographics; increasing avoidance towards advertisements; and shift towards interactive marketing. Almost half the total population of Bangladesh is below the age of 30 (Indexmundi.com, 2018), a generation that is more likely to avoid traditional advertisements (Brenner, 2015), due to the heavy dependence on the Internet. Perhaps, this explains why the top three mobile operators in Bangladesh, spent around BDT 1.04 billion in digital campaigns, where Grameenphone alone spent BDT 430 million (Islam, 2018). On the other hand, a significant rise in sales incentives by both the companies indicates that sales-force efforts are making a greater contribution to the financial return. However, greater analysis and in-depth information are required to understand the logic behind these findings.

This research is not free of limitations though. Taking into account few more companies from each industry, or a number of industries could have provided a bigger picture about the impact marketing expenses has on financial performance. Therefore, the findings of this particular study have revealed few gaps, which could be analysed further. It is important to explore the reasons behind an increasing budget for sales incentives and a decreasing budget for advertising, for which primary data collection would be necessary. Since, the financial reports gathered in this research do not provide a thorough breakdown or a clear indication regarding organization's digital marketing expenditure, the financial outcome of this marketing activity also needs attention.

\section{References}

Abratt, R., \& Smythe, M. (1989). A survey of sales incentive programs. Industrial Marketing Management, 18(3), 209-214. https://doi.org/10.1016/0019-8501(89)90037-0

Adcock, D. (2000). Marketing strategies for competitive advantage. Chichester: J. Wiley.

Bagwell, K. (2005). The Economic Analysis of Advertising. Handbook of Industrial Organization, 3, 1701-1844. https://doi.org/10.1016/S1573-448X(06)03028-7

Balasubramanian, S., \& Bhardwaj, P. (2004). When Not All Conflict Is Bad: Manufacturing-Marketing Conflict and Strategic Incentive Design. Management Science, 50(4), 489-502. https://doi.org/10.1287/mnsc.1030.0180

Behrman, D., \& Perreault, W. (1982). Measuring the performance of industrial salespersons. Journal of Business Research, 10(3), 355-370. https://doi.org/10.1016/0148-2963(82)90039-X

Bhasin, K. (2012). Here's How The Big 'No More Commission' Announcement At JC Penney Went Down. [Online] Available: https://www.businessinsider.com/heres-how-the-big-no-mor e-commission-announcement-at-jcpenney-went-down-2012-5 
Bracbank.com. (2018). BRAC Bank Limited | Reports and Statements | Financial Statements. [Online] Available: https://www.bracbank.com/Financial-Statements.php

Brenner, M. (2015). Millennials Hate Ads! Want This Instead. [Online] Available: https://marketinginsidergroup.com/content-marketing/millennials-hate-ads

Btrc.gov.bd. (2018). Mobile Phone Subscribers in Bangladesh January, 2018. [Online] Available: http://www.btrc.gov.bd/content/mobile-phone-subscribers-bangladesh-january-2018

Chowdhury, S. (2017). Measuring the Relationship among the Advertisement Expenditure, Sales Revenue and Profit on Steel Industries and Banking Industries in Bangladesh. European Journal of Business and Management, 9(9), 1-5.

Clark, B. (2000). Managerial Perspectives of Marketing Performance: Efficiency, Adaptability, Effectiveness and Satisfaction, Journal of Strategic Marketing, 8(1), 3-24. https://doi.org/10.1080/096525400346286

Deming, W. E. (1986). Out of the Crisis: Quality, Productivity and Competitive Position. Cambridge: Cambridge University Press.

Gautam, A. (2013). A study on (below the line) promotion strategies of telecom industry in western (UP) circle (India) with special reference to Reliance Communication. European Journal of Business \& Management, 5(22), 74-79.

Gbolagade, A., Adesola, M. and Oyewale, I. (2013). Impact of Marketing Strategy on Business Performance A Study of Selected Small and Medium Enterprises (SMEs) In Oluyole Local Government, Ibadan, Nigeria. IOSR Journal of Business and Management, 11(4), 59-66. https://doi.org/10.9790/487X-1145966

Grameenphone.com. (2018). Financial Report. [Online] Available:

https://www.grameenphone.com/about/investor-relations/ir-financial-report

Greuner, M., Kamerschen, D., \& Klein, P. (2000). The Competitive Effects of Advertising in the US Automobile Industry, 1970 - 94. International Journal of the Economics of Business, 7(3), 245-261. https://doi.org/10.1080/13571510050197177

Hooley, G., Greenley, G., Cadogan, J., \& Fahy, J. (2005). The performance impact of marketing resources. Journal of Business Research, 58(1), 18-27.

https://doi.org/10.1016/S0148-2963(03)00109-7

Hössjer, O. (2008). On the coefficient of determination for mixed regression models. Journal of Statistical Planning and Inference, 138(10), 3022-3038.

https://doi.org/10.1016/j.jspi.2007.11.010

Husain, I. (2017). Grameenphone posts $65 \%$ growth in data revenue. [Online] Available: https://www.dhakatribune.com/business/2017/04/23/grameenphone-posts-65-growth-data-rev enue

Indexmundi.com. (2018). Bangladesh Demographics Profile 2018. [Online] Available: https://www.indexmundi.com/bangladesh/demographics_profile.html 
Islam, M. (2016). Grameenphone expands its market footprints. [Online] Available: https://www.thedailystar.net/business/grameenphone-expands-its-market-footprints-1316530

Islam, M. (2018). Telcos spend Tk 104cr on digital marketing. [Online] Available: https://www.thedailystar.net/business/telecom/bangladeshi-mobile-operators-spend-taka-104c r-social-media-marketing-1641115

Jiménez, F., Posthuma, R., \& Campion, M. (2013). Effective incentive compensation for sales employees during tough economic times. Organizational Dynamics, 42(4), 267-273.

https://doi.org/10.1016/j.orgdyn.2013.07.004

John, G., \& Weitz, B. (1989). Salesforce Compensation: An Empirical Investigation of Factors Related to Use of Salary versus Incentive Compensation. Journal of Marketing Research, 26(1), 1-14. https://doi.org/10.1177/002224378902600101

Johnson, B. (2017). World's Largest Advertisers: Spending is Growing (and Surging in China). [Online] Available:

https://adage.com/article/cmo-strategy/world-s-largest-advertisers-2017/311484/

Jolibert, A., Mühlbacher, H., Flores, L., \& Dubois, P. (2012). Marketing Management. Basingstoke: Palgrave Macmillan. https://doi.org/10.1007/978-0-230-36367-0

Joshi, A., \& Hanssens, D. (2010). The Direct and Indirect Effects of Advertising Spending on Firm Value. Journal of Marketing, 74(1), 20-33. https://doi.org/10.1509/jmkg.74.1.20

Kambar, T. (2002). The Brand Manger's Dilemma: Understanding How Advertising Expenditure Affect Sales Growth during the Recession. The Journal of Brand Management, 10(2), 106-120. https://doi.org/10.1057/palgrave.bm.2540109

Kohn, A. (1993). Why Incentive Plans Cannot Work. Harvard Business Review, 71(5), 54-63.

Lee, J., Shin, B., \& Chung, I. (1996). Causality between advertising and sales: new evidence from cointegration. Applied Economics Letters, 3(5), 299-301.

https://doi.org/10.1080/135048596356393

Linson, S., \& Thomas, J. (2016). Effectiveness of Advertisement on Sales Turnover of Toilet Soap Manufacturing Industry. VISTAS, 5(1), 103-109.

Lodish, L., Abraham, M., Livelsberger, J., Lubetkin, B., Richardson, B., \& Stevens, M. (1995). A Summary of Fifty-Five In-Market Experimental Estimates of the Long-Term Effect of TV Advertising. Marketing Science, 14(3), G133-G140.

https://doi.org/10.1287/mksc.14.3.G133

Makadok, R. (2001). Toward a synthesis of the resource-based and dynamic-capability views of rent creation. Strategic Management Journal, 22(5), 387-401.

https://doi.org/10.1002/smj.158

Malhotra, M., \& Sharma, S. (2002). Spanning the continuum between marketing and operations. Journal of Operations Management, 20(3), 209-219.

https://doi.org/10.1016/S0272-6963(02)00019-0 
Morgan, N. (2011). Marketing and business performance. Journal of the Academy of Marketing Science, 40(1), 102-119. https://doi.org/10.1007/s11747-011-0279-9

Narver, J., \& Slater, S. (1990). The Effect of a Market Orientation on Business Profitability, Journal of Marketing, 54(4), 20-35. https://doi.org/10.1177/002224299005400403

Nijs, V., Dekimpe, M., Steenkamps, J., \& Hanssens, D. (2001). The Category-Demand Effects of Price Promotions. Marketing Science, 20(1), 1-22.

https://doi.org/10.1287/mksc.20.1.1.10197

O'Reilly, N. (2014). Can Commission Incentives Save J.C. Penney?. [Online] Available: https://www.fool.com/investing/general/2014/01/30/can-commission-incentives-save-jc-penn ey.aspx

Okyere, N., Agyapong, G., \& Nyarku, K. (2011). The Effect of Marketing Communications on the Sales Performance of Ghana Telecom (Vodafone, Ghana). International Journal of Marketing Studies, 3(4), 50-62. https://doi.org/10.5539/ijms.v3n4p50

Osinga, E., Leeflang, P., Srinivasan, S., \& Wieringa, J. (2011). Why Do Firms Invest in Consumer Advertising with Limited Sales Response? A Shareholder Perspective. Journal of Marketing, 75(1), 109-124. https://doi.org/10.1509/jmkg.75.1.109

Piercy, N., Cravens, D., \& Morgan, N. (1998). Salesforce performance and behaviour - based management processes in business - to - business sales organizations. European Journal of Marketing, 32(1/2), 79-100. https://doi.org/10.1108/03090569810197480

Pride, W., \& Ferrell, O. (1997). Marketing. 2nd edition. Boston: Houghton Mifflin Company.

Quadir, K. (2015). The Story of bKash. [Online] Available:

https://www.thedailystar.net/the-story-of-bkash-21235

Rehman, M., Shaikh, T., \& Sattar, M. (2015). Relationship between Marketing Strategies and Firms' Financial Performance in Food Producers Sector of Pakistan. Journal of Marketing and Consumer Research, 17(1), 65-79.

Riaz, S., Furqan, M., \& Sidique, S. S. (2015). The Impact of Advertising on the Profitability of Public \& Private Sector Commercial Banks. European Journal of Business and Management, 7(28), 117-124.

Richards, J., \& Curran, C. (2002). Oracles on "Advertising": Searching for a Definition. Journal of Advertising, 31(2), 63-77.

https://doi.org/10.1080/00913367.2002.10673667

Ryals, L., \& Rogers, B. (2005). Sales compensation plans - One size does not fit all. Journal Of Targeting, Measurement And Analysis For Marketing, 13(4), 354-362. https://doi.org/ 10.1057/palgrave.jt.5740162

Ryan, T. (2014). Did J.C.Penny make a mistake eliminating sales commission. [Online] Available: https://www.retailwire.com/discussion/did-j-c-penney-make-a-mistake-eliminatin g-sales-commissions 


\section{Macrothink}

Business and Economic Research

ISSN 2162-4860

2019, Vol. 9, No. 1

Sharma, J., \& Husain, S. (2015). Marketing Expenses \& Profitability: Evidence from

Telecom Sector in Kingdom of Saudi Arabia. European Journal of Business and Management, 7(35), 66-70.

Simester, D., Hu, Y., Brynjolfsson, E., \& Anderson, E. (2009). Dynamics of Retail Advertising: Evidence from a Field Experiment. Economic Inquiry, 47(3), 482-499. https://doi.org/10.1111/j.1465-7295.2008.00161.x

Spiro, R., Rich, G., \& Stanton, W. (2003). Management of a sales force. 11th ed. India: Tata McGraw-Hill.

Srinivasan, S., \& Hanssens, D. (2009). Marketing and Firm Value: Metrics, Methods, Findings, and Future Directions. Journal of Marketing Research, 46(3), 293-312. https://doi.org/10.1509/jmkr.46.3.293

Sudarsan, P. K. (2007). Evaluating Effectiveness of Advertising on Sales: A Study Using Firm Level Data. The IUP Journal of Managerial Economics, 54-62.

The Daily Star. (2017). Mobile money a monopolistic market: official. [Online] Available: https://www.thedailystar.net/business/mobile-money-monopolistic-market-official-1358230

Wang, H. D. (2018). On the money in Bangladesh with bKash - Huawei Publications. [Online] Available: https://www.huawei.com/en/about-huawei/publications/winwin-magazin e/30/on-the-money-in-bangladesh-with-bkash

Zoltners, A., Sinha, P., \& Lorimer, S. (2008). Sales Force Effectiveness: A Framework for Researchers and Practitioners. Journal of Personal Selling \& Sales Management, 28(2), 115-131. https://doi.org/10.2753/PSS0885-3134280201

Zoltners, A., Sinha, P., \& Lorimer, S. (2012). Breaking the Sales Force Incentive Addiction: A Balanced Approach to Sales Force Effectiveness. Journal of Personal Selling \& Sales Management, 32(2), 171-186. https://doi.org/10.2753/PSS0885-3134320201

\section{Copyright Disclaimer}

Copyright for this article is retained by the author(s), with first publication rights granted to the journal.

This is an open-access article distributed under the terms and conditions of the Creative Commons Attribution license (http://creativecommons.org/licenses/by/3.0/). 